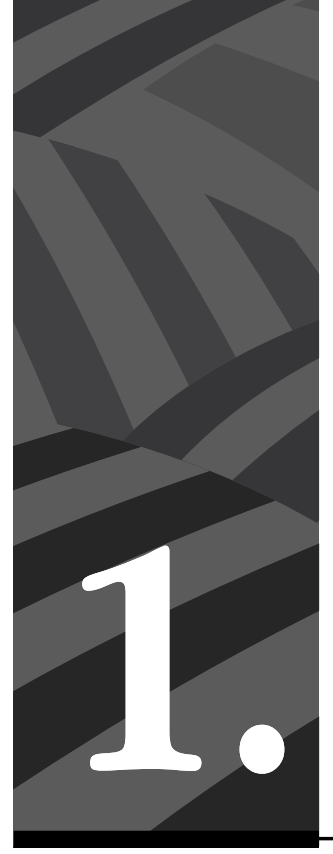

El Parque del «Descabezado» o de Camilo Torres y

las luchas sociales en

Barrancabermeja en

los años ochenta 


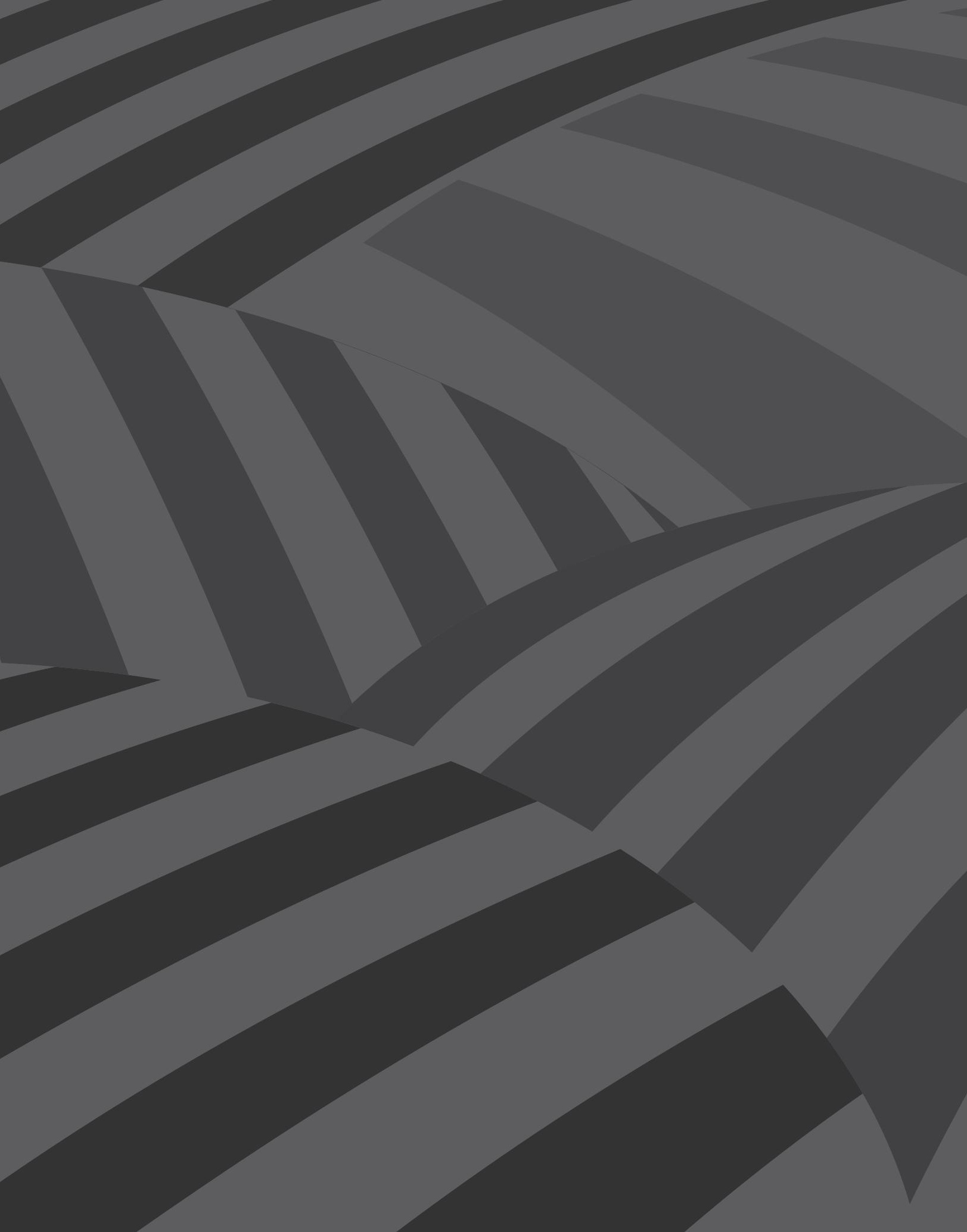




\section{El Parque del «Descabezado» o de Camilo Torres y las luchas sociales en Barrancabermeja en los años ochenta}

Por Mauricio Archila Neira*

Resumen: El parque del «Descabezado» o de Camilo Torres en Barrancabermeja hace parte de las memorias disputadas en torno a la destrucción del monumento a Camilo Torres en 1986 - a los 20 años de su muerte-, en medio de un auge de luchas en el país y en el Magdalena Medio. Luego de una reflexión sobre la memoria colectiva y los monumentos, se indaga sobre la historia del monumento, sus gestores iniciales y los varios ataques que recibió hasta la reconstrucción reciente del actual parque. Esta disputa obliga a mirar las luchas populares en el Magdalena Medio en el segundo lustro de los años ochenta, con la violencia que se incrementará en ese auge, de la cual el episodio del «Descabezado» es solo una representación simbólica.

Palabras clave: Magdalena Medio, Barrancabermeja, luchas populares, Parque Camilo Torres, violencia

* Ph. D. en Historia, profesor titular de la Universidad Nacional de Colombia e investigador asociado de Cinep. Agradezco al historiador barranqueño Rafael Velásquez Rodríguez su desinteresada colaboración en la recolección de información escrita, visual y oral para esta investigación, y por sus oportunos comentarios a este texto. Igualmente, a todos los entrevistados por darme luces al respecto y en especial a Vicente Zamudio, quien, como estudiante en ese entonces de la Universidad Nacional, estuvo presente en los eventos conmemorativos en Barrancabermeja y Patio Cemento y tomó fotos, algunas de las cuales nos cedió para este artículo. Asimismo, a los integrantes del equipo de movimientos sociales de Cinep por la rica discusión del texto, y especialmente a Martha Cecilia García por el apoyo de todo tipo en esta pesquisa. 


\section{The «Beheaded» or Camilo Torres Park and the Social Struggles in Barrancabermeja in the Eighties}

Abstract: The "Beheaded" or Camilo Torres Park in Barrancabermeja is a part of the memories disputed over the destruction of the monument to Camilo Torres in 1986-20 years after his death-in the context of increasing social struggles in the country and the Middle Magdalena region. After discussing collective memory and monuments, this paper examines the history of this particular monument in Barrancabermeja, its promoters and the numerous attacks it received until the recent reconstruction of the park. The dispute over memory in this case leads to a discussion on the people's struggle in the Middle Magdalena region in the second half of the 1980s, and the increasing violence, of which the episode of the beheaded statue of Camilo Torres is just a symbolic representation.

Keywords: Middle Magdalena, Barrancabermeja, people's struggles, Camilo Torres Park, violence

Cómo citar este artículo: Archila Neira, Mauricio (2019). El Parque del «Descabezado» o de Camilo Torres y las luchas sociales en Barrancabermeja en los años ochenta. Revista Controversia, 213, 17-52.

Fecha de recepción: 26 de marzo de 2019

Fecha de aprobación: 27 de mayo de 2019

Una vez nos damos cuenta que la memoria «colectiva» es algo más que la individual, ya no podemos describirla como una expresión directa y espontánea de la pena, el luto o el escándalo, sino como una formalización igualmente legítima y significativa, mediada por ideologías, discursos, sentido común e instituciones.

(Portelli, 1997, pp. 157-158).

(...) el lugar de la memoria es un lugar doble: un lugar de exceso cerrado sobre sí mismo, cerrado sobre su identidad y concentrado sobre su nombre, pero constantemente abierto sobre la extensión de sus significaciones.

(Nora, 2008, p. 38). 
Honrar la memoria de la comunidad ha estado presente en todos los pueblos conocidos; borrar la memoria del enemigo es algo tan antiguo como la destrucción de Cartago. (Achugar, 2003, p. 198).

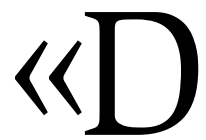
esconocidos descabezan el busto de Camilo Torres», tituló Vanguardia Liberal (16 de febrero de 1986) la noticia sobre el atentado cometido en Barrancabermeja contra el monumento en homenaje al sacerdote muerto en combate 20 años antes. Según versiones recogidas por el periódico, en la madrugada del sábado 15 de febrero de 1986 «cinco hombres armados llegaron en un campero verde del que descendieron y mientras uno subía al monumento con una porra en la mano, los restantes cuatro individuos con metralletas rodeaban el sitio» (p. 13). La revista cristiana Solidaridad, que estuvo presente en la ciudad durante esos días, informó posteriormente sobre el hecho con otros detalles: cinco personas con ametralladoras llegaron en un jeep, «pusieron manos arriba a los trabajadores que habían madrugado para continuar el trabajo», uno de ellos se subió al monumento en forma de $\mathbf{V}$ para «proceder a golpear a punta de mazo la cabeza (del busto) hasta hacerla desprender del resto del bronce» (n. ${ }^{\circ} 72$, marzo de 1986, p. 32) ${ }^{1}$. Se dice también que meses después otros desconocidos destruyeron el resto del busto (entrevista a Pedro Chaparro, 2019 y video de Acuña, 2010), algo que también ocurrió en Patio Cemento -el sitio exacto de la muerte de Camilo- en donde se había montado un altar con una cruz y una placa que contenía una leyenda alusiva al sacerdote guerrillero (Vanguardia Liberal, 13 de marzo de 1986, p. 13). Aunque

1 Sobre los responsables, muy tempranamente surgió la idea de que habían sido fuerzas del orden por aquello del campero o jeep de color verde y las ametralladoras. La revista Solidaridad responsabiliza escuetamente a los «paramilitares». Vanguardia Liberal dice genéricamente que fue la "derecha», pero menciona una versión que atribuye el hecho al Ejército de Liberación Nacional (ELN), el cual lo desmintió inmediatamente. En entrevista con Pedro Chaparro (enero de 2019), nos afirmó que en 1998, cuando estaba preso, conoció a un paramilitar llamado El Indio, quien le confesó que había sido la Armada Nacional la que había ejecutado el atentado con un hacha. 
hay algunas variantes de esa versión de los hechos, especialmente desde los recuerdos reconstruidos posteriormente, ese es el núcleo básico de la narrativa del «Descabezado», como se conoció por mucho tiempo al parque Camilo Torres Restrepo en Barrancabermeja, lugar de disputa por la memoria en torno al conocido sacerdote revolucionario.

Para entender estas luchas por el significado del pasado, haremos una aproximación conceptual y metodológica al tema, para luego ubicar brevemente el contexto de las luchas sociales en el puerto petrolero y en la región del Magdalena Medio. Posteriormente, analizaremos los avatares del proyecto de conmemoración de los 20 años de la muerte de Camilo, con el fin de retornar al escenario de la violencia en la conflictiva región, y desde allí extraer conclusiones sobre el significado de los eventos descritos.

\section{Memorias y monumentos}

La disputa por la memoria «colectiva», de la que nos habla Alessandro Portelli (1997) en el primer epígrafe, no será solamente por el nombre del parque, por los sucesos concretos de esos días o por los eventuales victimarios, sino, sobre todo, por el significado de los atentados que buscaban borrar la memoria de Camilo Torres Restrepo en Barrancabermeja y en el país. Ahí se hace evidente que esa memoria colectivamente construida está mediada por los intereses de quienes la alimentan o la debilitan. En efecto, la memoria, como lo hemos señalado en otra parte (Archila, 2017), es siempre materia de disputa, pues consiste en traer activamente el pasado al presente. Se trata de una materia viva que se apoya en la experiencia subjetiva pasada, y se recrea en los contextos, ideologías e intereses del presente. Según Maurice Halbwachs (2004), aunque la memoria se ejerce individualmente, suele estar moldeada por marcos sociales, máxime cuando se vuelve colectiva.

Un aspecto que importa destacar en esta investigación es la dimensión espacial de las memorias. Para el mismo Halbwachs, «no hay memo- 
ria colectiva que no se desarrolle dentro de un marco espacial» (2004, p. 144). Los espacios físicos están cargados de significados, por lo que son un punto de referencia obligado del recuerdo social y ofrecen estabilidad a los grupos que directa o indirectamente están ligados a ellos. No sobra señalar que, de acuerdo con Reinhart Koselleck, el tiempo histórico es la articulación entre «el espacio de la experiencia y el horizonte de expectativas» (1993, cap. 14). El espacio de la experiencia suele alimentar los recuerdos de los grupos humanos, especialmente en los pueblos indígenas, como oportunamente lo señalan los antropólogos. A Joanne Rappaport (1990), por ejemplo, le llama la atención la utilización de la geografía para enmarcar y contextualizar la historia de los nasa en el Cauca, una geografía sacra que permite revivir cotidianamente lo ocurrido y refuerza la continuidad moral del pasado en el presente. Por tanto, sus territorios son «documentos» para interpretar el pasado (cap. 6). Así, se entiende también que la memoria para ellos sea recorrer caminos hacia lugares cargados de significado. A su vez, para Herinaldy Gómez, los indígenas colombianos y americanos en general no separan el ser humano de la naturaleza; su historia no se narra sobre un eje temporal, como en Occidente, sino espacial: el territorio «es el texto donde se produce y lee la historia» (Gómez, 2000, p. 28).

Esto también funciona para otros grupos rurales y urbanos, aunque no estén tan ligados a la noción de territorio, porque, quiérase o no, la memoria tiene siempre un referente espacial. Pero, además, los seres humanos dotamos algunos espacios de un significado destacado, para convertirlos en lo que se ha llamado «lugares de la memoria». Con esta operación, según Elizabeth Jelin y Victoria Langland (2003), «lo que antes era un mero "espacio" físico o geográfico se transforma en un "lugar” con significados especiales» (p. 3).

La expresión «lugares de la memoria» ha sido ampliamente difundida por el historiador francés Pierre Nora, quien los considera como espacios para detener el tiempo, bloquear el olvido, inmortalizar la muerte, materializar lo inmaterial y en últimas escapar de la historia (2008, 
pp. 33 y 38). No sin razón se le ha criticado por extender demasiado la categoría, hasta incluir cualquier ámbito, no solo espacial, como «lugar de la memoria» (Achugar, 2003, p. 211) y por mostrar un tono elegiaco de nostalgia por el pasado imperial francés a la hora de designar lo que a su juicio son esos lugares (Achugar, 2003, p. 203 y Anderson, 2008, pp. 202-207)2 ${ }^{2}$ Con todo, es muy poderosa la imagen de la existencia de espacios privilegiados para la memoria que, como lo dice una de las citas iniciales del mismo Nora, tienen arraigo local, hasta por el nombre, pero sus significados se proyectan más allá de ese ámbito ${ }^{3}$.

En la perspectiva de Hugo Achugar, los monumentos comparten mucho de lo que Nora señalaba para los «lugares de la memoria»: ante la fugacidad del presente, intentan fijar la memoria en el tiempo, por sus mismas características cruzan el eje temporal con el espacial y articulan pasado y futuro, pues pretenden dar un mensaje perenne a las generaciones futuras. Pero, lo que más nos interesa resaltar de su reflexión sobre los monumentos es que son formas de memoria pública que expresan disputas por el poder (2003, pp. 192-193). Esto lo ratifican las compiladoras del libro en el que él escribe. En efecto, para Jelin y Langland (2003, pp. 2-3) los monumentos son espacios públicos reconocidos por el Estado, que arrastran luchas sociales y políticas en torno a las figuras a exaltar, los mensajes para perennizar, los espacios concretos de ubicación de las estatuas y aun su diseño estético. Estas disputas son ejemplificadas por Katherine Hite cuando se refiere al monumento en honor de Salvador Allende en la Plaza de la Constitución,

2 Ignorar lugares en los que Francia comprometió sus ideales republicanos y democráticos como Argelia y Vietnam, a juicio de Perry Anderson (2008), no es un olvido circunstancial, hace parte de un programa político-ideológico que Nora comparte con su cuñado, François Furet, ambos discípulos de Raymond Aron, de liberalizar a Francia deslegitimando a los extremos radicales como el comunismo o el gaullismo, herederos ambos del jacobinismo. Esta labor pretende eliminar los vestigios de esas tradiciones consideradas perniciosas por el centro político, y es calificada por Anderson como la imposición de un «pensamiento tibio».

3 Jelin y Langland, a su vez, señalan que estos lugares, por tener un marco territorial, son locales y localizados, pero sus sentidos son de distinta escala (2003, p. 14). 
contigua a la Casa de la Moneda en Santiago de Chile (2003, pp. 19-55). Tras el largo debate parlamentario en el que finalmente se aprobó el monumento, vino la polémica por su ubicación precedida por antiguos contrincantes — como Jorge Alessandri y Eduardo Frei, además del prócer decimonónico Diego Portales-, que derivó en una disputa estética, pues la obra fue encargada a un escultor de derechas Arturo Hevia. Pero allí no paró la confrontación pública; luego vino la disputa por la apropiación de la memoria del presidente muerto en el golpe militar de 1973, que comenzó con la inauguración en septiembre de 2000, cuando todavía el perpetrador del golpe estaba vivo y temporalmente detenido en Londres por orden de un juez español ${ }^{4}$.

$\mathrm{Y}$ es que, precisamente el monumento -o ciertos monumentos, especialmente los del tiempo presente en sociedades que han vivido procesos de aguda violencia sociopolítica-, en el decir de James Young, «se transforma en un lugar de combate y pugna de significados (...) un sitio de conflicto cultural» (citado por Jelin y Langland, 2003, p. 10). A lo que las autoras agregan: «una vez un lugar se convierte en convocante, el juego de las memorias sobre las memorias se torna central» (Jelin y Langland, 2003, p. 14). Allí se librarán choques entre quienes quieren revivir una memoria y quienes quieren enterrarla, como señalaba Achugar en el último epígrafe. Sin embargo, no es solo una disputa entre las distintas memorias que convergen en el presente, sino que el debate se proyecta al futuro. A pesar de que los monumentos tratan de grabar en la piedra o en el bronce una memoria para sacarla del tiem$\mathrm{po}^{5}$, no hay garantía de que el significado atribuido hoy dure eterna-

4 En el caso que analizamos en estas páginas, se dieron similares pugnas sociopolíticas y debates académicos, aunque en menor escala, pues se trataba de un homenaje en una ciudad intermedia, ni siquiera capital de departamento, y no propiamente en su plaza central. Además, y no menos importante, fue una iniciativa promovida desde abajo, aunque contó con el aval de la institucionalidad municipal. En cuanto al debate estético, fue más por el conjunto del monumento que por la escultura o el busto de Camilo Torres como tal.

5 La antropóloga Katherine Verdeny dice al respecto: «las estatuas son personas vaciadas de bronce o talladas en piedra (...), la estatua altera la temporalidad 
mente, pues siempre está abierto a nuevos sentidos (Jelin y Langland, 2003, p. 15) como ha ocurrido con muchos países de la Europa del este tras la caída del socialismo realmente construido o en España con el fin de la dictadura franquista.

Fijar en la memoria local, regional y nacional el legado del sacerdote revolucionario era lo que se pretendía hacer con el Parque Camilo Torres Restrepo en febrero de 1986; pero la serie de ataques a su monumento truncaron temporalmente esa consagración icónica. De alguna manera en Barrancabermeja estalló, en forma muy temprana, la disputa por los significados no solo de su pasado, sino sobre todo de su proyección futura. Por esto, mientras sectores sociales y políticos locales y nacionales promovían con entusiasmo el homenaje a Camilo, otros, desde las sombras, buscaban erradicar de raíz su legado. No lo lograron, pero sí causaron bastante daño. Veamos entonces los avatares de esa conmemoración, contextualizados en la dinámica de las luchas sociales en la ciudad y en la región.

\section{El contexto local y regional}

Desde los inicios de la explotación petrolera en los años veinte del siglo pasado, Barrancabermeja destacó en el concierto nacional como la cuna de un movimiento obrero radical y nacionalista (Archila, 1991 y Vega et al., 2004), que luego se articuló a un movimiento popular urbano desde mediados de siglo. Después del 9 de abril de 1948 -experiencia conocida como la «Comuna de Barranca» (Buenahora, 1971 y Díaz, 1988) - , a las huelgas obreras y al corto ejercicio de poder popular se les van a sumar los paros cívicos de los años sesenta y setenta, en primer lugar, por servicios públicos domiciliarios, especialmente el agua, y luego por el derecho a la vida, dado el desborde de la violencia de mediados de los años ochenta (García, 2006). Aunque esta trayectoria

asociada a ella, colocándola en el terreno de lo intemporal o de lo sagrado, como un "ícono"» (citada por Hite, 2003, p. 52). 
de lucha y resistencia se prestó para estigmatizar al puerto petrolero - como en general se hizo con el Magdalena Medio al designarlo como zona «roja» (Vargas, 1992) - , también ha sido garantía de un ejercicio activo de ciudadanía deliberante y participativa (entrevistas a Chaparro y Ravelo, 2019).

Así lo retrata la figura 1, que muestra la oscilante protesta social en Barrancabermeja según la Base de Datos de Luchas Sociales (BDLS) del Cinep. El puerto petrolero tuvo un total de 713 acciones sociales colectivas entre 1975 y 2018, casi un $3 \%$ del total del país, con un promedio cercano a 16 luchas anuales -más de una por mes-, lo que es relativamente alto para una población intermedia. De hecho, esta es la primera ciudad no capital de departamento que figura en las estadísticas de la BDLS y la séptima en el escalafón nacional.

Figura 1

Luchas sociales en Barracabermeja 1975 - 2018

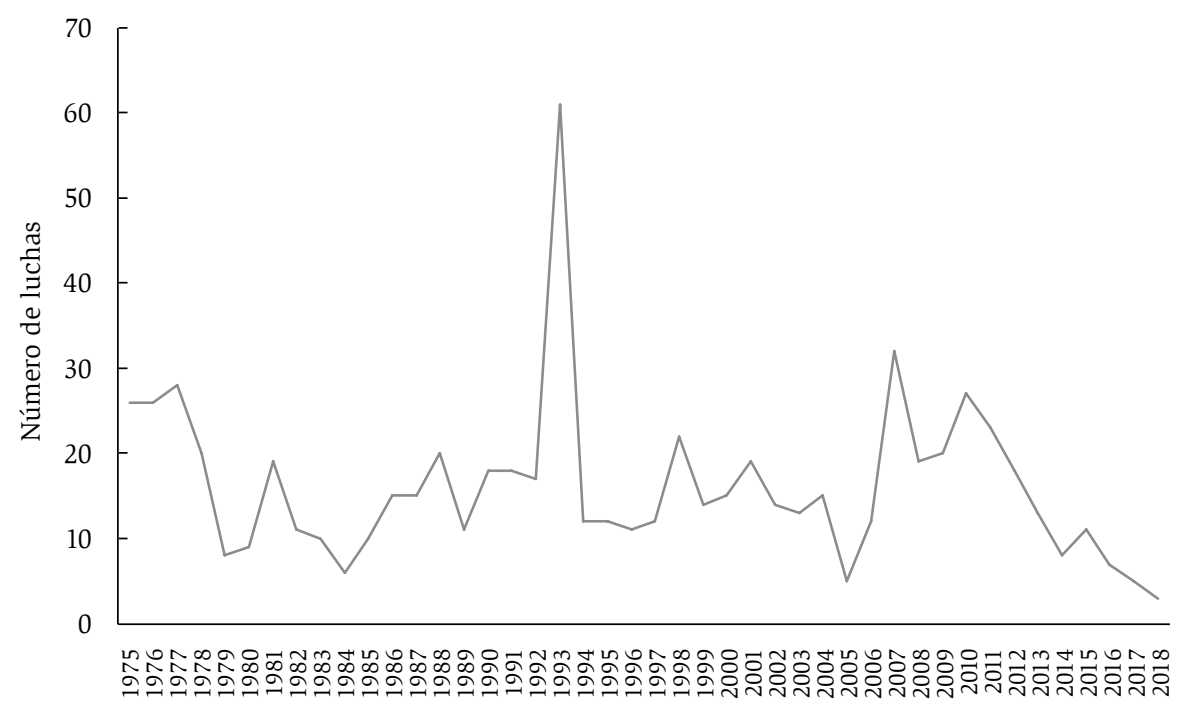

Fuente: BDLS de Cinep. 
Como se constata en la figura 1, la trayectoria de las luchas sociales en Barranca es más o menos constante, salvo el pico de 1993, cuando se dio una inusitada ola de invasiones de predios urbanos; no obstante, inicia un cierto declive después de 2013, un poco más pronunciado que el conjunto del país (Archila et al., 2019, cap. 1). En todo caso, para los años ochenta, era uno de los municipios más activos en términos de agitación social y política, a pesar de la violencia que se cernía sobre la ciudad.

En efecto, Barrancabermeja, como muchas poblaciones del Magdalena Medio y en general de reciente colonización en el país, históricamente tuvo expresiones de una cultura que en su momento llamamos radical (Archila, 1986). Por eso, no es de extrañar que la ciudad y la región hayan estado abiertas a prédicas nacionalistas y revolucionarias (Vargas, 1992), máxime cuando se trataba de la defensa de un recurso natural como el petróleo. Desde los tiempos del socialismo revolucionario de los años veinte hasta las izquierdas de los años ochenta, pasando por el comunismo, el gaitanismo y el Movimiento Revolucionario Liberal (MRL) —en el que militó Rafael Rangel, una figura cercana al puerto petrolero y alcalde revolucionario en los días de la «comuna de Barranca»-, la ciudad siempre fue tierra abonada para discursos contestatarios.

A lo largo de esta historia de lucha, ha sido tradicional el liderazgo de la Unión Sindical Obrera (USO) y luego de la Coordinadora Popular de los años ochenta, que integraba organizaciones sindicales, los pobladores urbanos, la Organización Femenina Popular (OFP), el clero progresista y los medianos sectores empresariales. A partir de los años noventa, los liderazgos recaerán en las organizaciones defensoras de los derechos humanos (García, 2006). También en la década de los ochenta se dio el despliegue de organizaciones sociopolíticas como ¡A Luchar!, la Unión Patriótica (UP), el Frente Amplio del Magdalena Medio (FAM) y, en menor escala, el Frente Popular (FP) y la Alianza Democrática, 
Movimiento 19 de abril (AD-M19) ${ }^{6}$. En esta tradición de rebeldía social y de discursos contestatarios, incluso los grupos insurgentes llegaron a tener alguna simpatía, lo que los hizo envalentonarse e irrumpir públicamente para hacer alarde de sus armas en medio de las protestas populares a fines de los años ochenta y comienzos de los noventa (Chaparro, 1991). En los últimos años eso ha ido cambiando, máxime desde la incursión violenta del paramilitarismo en la región a fines del siglo pasado (García, 2006), tema que abordaremos más adelante en este artículo.

En tal contexto se entiende la entusiasta acogida que tuvo Camilo Torres Restrepo en 1965 en su paso por el puerto (Prieto, 2019). Como se sabe, la fugaz trayectoria política del sociólogo sacerdote se vio abruptamente cortada por su ingreso a la guerrilla en octubre de ese año y su pronta muerte en combate el 15 de febrero de 1966 (Archila, 2017). El legado de Camilo, con todo, no murió ese día, sino que siguió vivo en el mundo sindical y popular de la ciudad y del país. De lo anterior dará cuenta no solo el parque motivo de estas páginas, sino el amplio despliegue de luchas campesinas y populares de los años ochenta orientadas por grupos cercanos o proclives al camilismo como lo eran ¡A Luchari y el mismo $\mathrm{FAM}^{7}$. De hecho, por los días del atentado al monumento de marras, habían llegado a Barrancabermeja cerca de 3000 campesinos

6 En el archivo documental de ¡A Luchar! - recopilado y conservado por Diego Mauricio Fajardo - hay un reporte sobre la cobertura del paro del Nororiente de junio de 1987, con cifras aparentemente bajas para Barranca, mil campesinos, cuando en Ocaña se habla de 25000 , en Valledupar de 20000 o en Saravena de 15000. Por los días de la inauguración del Parque Camilo Torres, la UP y el FAM eran muy activos en el puerto petrolero. Incluso, por allí pasó Jaime Pardo Leal en su calidad de candidato presidencial de la UP (Vanguardia Liberal, 14 de febrero, 1986, p. 16 y 25 de febrero, 1986, p. 11).

7 Este grupo fue creado en los años ochenta por Ricardo Lara Parada, un excomandante del ELN desmovilizado, al que sus antiguos compañeros de armas acusarían de traidor y ejecutarían el 15 de noviembre de 1985 (García, 2006, p. 287). 
provenientes de Yondó, víctimas de la masacre de la Vuelta Acuña de 1984 (Prada, 2006, p. 188) ${ }^{8}$.

\section{La conmemoración}

Como decíamos en el contexto anterior, Camilo Torres Restrepo pasó por el puerto petrolero en su corta carrera política, exactamente el 24 de julio de 1965, según testimonia la lideresa popular Luisa Delia Piña (Velásquez, 2015, p. 106) ${ }^{9}$. A los tres años de la muerte de Camilo, su madre, Isabel Restrepo, fue invitada por la misma Luisa Delia y otros líderes de izquierda de la ciudad. Así lo recuerda la lideresa popular: «el 15 de febrero del 69 (...) nos cogimos a la brava una franja de terreno donde ahora está la plaza (sic) Camilo Torres Restrepo y pusimos un pedestal grandísimo que pesaba como 100 arrobas construido en concreto para ponerle una placa y traer a Isabelita» (citada en Arenas, 1999, p. 76). Rememora incluso el contenido de la placa ${ }^{10}$, pero a todas luces

8 Este éxodo campesino ha sido narrado literariamente por la periodista Marbel Sandoval Ordoñez (2018). La prensa regional señala que algunos miembros de la Comisión de Paz nombrada por el presidente Belisario Betancur se hicieron presentes en el puerto petrolero para negociar el fin de la movilización campesina, que amenazaba con volverse una crisis humanitaria en la ciudad y la región. Vanguardia Liberal menciona los nombres de John Agudelo Ríos, Carlos Morales y el padre Nel Beltrán, además de Braulio Herrera, delegado de las FARC para adelantar la acción política (2 de febrero, 1986, p. 13; 26 de febrero, 1986, p. 11; y 4 de marzo, 1986, p. 13). Incluso el mismo periódico luego muestra a algunos de los miembros de dicha Comisión que van a Patio Cemento a constatar los actos vandálicos allí cometidos contra el otro monumento a Camilo, días después de ser consagrado (Vanguardia Liberal, 13 de marzo, 1986, p. 13).

9 De acuerdo con Rafael Velásquez Rodríguez (2015), quien hace la semblanza de esta lideresa, «Luisa fue a recibirlo al aeropuerto. Ella nunca olvidó esa experiencia, porque "no se había visto en la historia de Barranca una manifestación tan grandiosa como esta y el pueblo emocionado gritaba ¡Viva Camilo Torres!, ¡Viva el pueblo de Barranca! Era una sola voz". La USO invitó a una cena de recibimiento en el restaurante El Bosque». Al final de ese texto se anexa una foto en la que aparece ella con Camilo y Diego Montaña Cuéllar, entre otros, en ese restaurante (p. 106).

10 Según el testimonio de Piña, recogido por Arenas (1999), la placa rezaba (literalmente) así: «CAMILO SÍMBOLO DE LA UNIDAD REVOLUCIONARIA NO ESTÁ ENTERRADO, ESTÁ SEMBRADO Y VIVE AUN PARA LIBERTAD (sic) DE LOS PUEBLOS DE AMÉRICA. UNIÓN Y LIBERACIÓN». 
mezcla tiempos históricos, pues el pedestal como tal solo se pondrá 20 años después. Lo que se puso en febrero de 1969 fue la «primera piedra» del futuro monumento (Vanguardia Liberal, 17 de febrero, 1986, p. 11).

Otro detalle que Luisa Delia Piña recuerda, en lo que sí converge con varios testimonios posteriores, es la intención de bautizar el barrio vecino con el nombre del cura revolucionario. En efecto, se trataba de un barrio nuevo construido por Ecopetrol como resultado de una convención de la uso (entrevista a Prieto, 2019) en terrenos del antiguo aeropuerto (entrevista a Pinzón 2019). En un video recientemente grabado en Youtube, un líder social e integrante de la Junta de Acción Comunal (JAC) del barrio de la época, Marco Tulio Aguirre, dice que hubo una votación entre las casi 500 familias que habitaban el barrio y ganó el nombre del antiguo gerente de Ecopetrol, Mario Galán, padre del futuro político Luis Carlos Galán (ver también entrevista a Prieto, 2019). Por eso, quienes querían rendir un homenaje a Camilo Torres Restrepo decidieron darle este nombre al parque que estaba por construirse a la entrada del barrio. Pasarán muchos años para que se retomara el proyecto del homenaje, en parte porque, a juicio de Fernando Acuña (video, 2010), la USO descuidó el asunto por estar concentrada en las huelgas de 1971 y 1977 (Vega et al., 2004).

Un par de años antes de cumplirse el $20^{\circ}$ aniversario de la muerte de Camilo Torres Restrepo, sectores sindicales liderados por Fedepetrol y la uso retomaron la iniciativa y comenzaron a recoger dineros y a buscar apoyos en la administración local (Colombia Hoy, 42, 1986, p. 4) ${ }^{11}$. En un primer momento lograron concentrar la suma de dos millones de pesos (Vanguardia Liberal, 16 de enero de 1986, p. 13). También contaron con el apoyo unánime del concejo municipal y con la colaboración

11 Pedro Chaparro señala que el grupo sociopolítico ¡A Luchar!, al que él pertenecía en calidad de responsable político, apoyaba la iniciativa sindical (entrevista, 2019). Otros sindicatos y federaciones que figuran entre los organizadores fueron: Asitlan, Fenasintrap, Sindicato de Educadores de Santander, Sintradepartamento de Antioquia, Sintracicolac, Sintranestlé y Usitras (Colombia Hoy, 42, 1986, p. 4). 
de Planeación Local y de la Secretaría de Obras Públicas del municipio. Los coordinadores, Fernando Acuña, presidente de Fedepetrol; Alfredo Gómez, del centro de investigaciones de Fedepetrol y Pedro Chaparro, miembro de la USO y responsable político de ¡A Luchar!, diseñaron con suficiente antelación un proceso participativo para celebrar el homenaje (entrevista a Chaparro, 2019). Esta amplia participación parece ser única en las historias de construcción de los monumentos, que suelen recaer en los hombros de pocas personas, especialmente vinculadas a la institucionalidad o a las vetustas academias de historia. De esta manera iniciaron la recolección de recursos monetarios directamente con la población o a través de la donación de llaves ${ }^{12}$, estimularon el trabajo voluntario para la construcción del parque y del monumento y planearon actos públicos no solo en las efemérides, sino en días previos. De esta forma organizaron, por ejemplo, un campeonato de fútbol de salón, con el fin de recoger dineros, el cual ¡llegó a tener un equipo camilista! (entrevista a Chaparro, 2019).

La construcción del parque y del monumento fue relativamente rápida, tomó menos de un mes (Video a Acuña, 2010 y entrevista a Chaparro, 2019). En las obras colaboraron trabajadores petroleros y de otros sindicatos, habitantes de los barrios vecinos, estudiantes y hasta campesinos presentes en la ciudad por el ya señalado éxodo. El proceso fue mostrado por la prensa regional: primero la limpieza del terreno y luego, paso a paso, la construcción de la obra (Vanguardia Liberal, 15, 16 y 25 de enero de 1986, p. 13) ${ }^{13}$. Sobre las ideas de los coordinadores, el arquitecto Edgar Cote Gravino hizo el diseño del monumento y agregó la propuesta de una $\mathbf{V}$ truncada, como de una victoria incompleta con base en la trayectoria de Camilo Torres-, mientras que el artista Dagoberto Güiza Salas esculpió el busto, que supuestamente estuvo listo desde meses antes en la sede de Fedepetrol (Vanguardia Liberal,

12 No queda claro en la entrevista para qué se iban a utilizar, si para venderlas y recoger plata de ahí, o si era para fundirlas y que sirvieran para la escultura.

13 Estos reportes suelen incluir fotos ilustrativas del proceso. 
17 de febrero de 1986, p. 11) ${ }^{14}$. La $\mathbf{V}$ truncada estaba apoyada sobre una base que tenía unas ondulaciones que semejaban montañas y en donde iban a estar esculpidas figuras de animales para representar al campo colombiano, escenario clave de la lucha de Camilo. La obra incluía una placa al pie de la base con la siguiente leyenda: «La constante lucha revolucionaria del pueblo completará la V de la victoria / A los 20 años de su muerte en combate CAMILO vive, 1966-febrero $15-1986 »^{15}$.

El pedestal y la $\mathbf{V}$ truncada se fundieron a comienzos de febrero (Vanguardia Liberal, 2 de febrero de 1986, p. 13) sobre una estructura de madera diseñada por un maestro remodelador de iglesias (entrevista a Chaparro, 2019). Fue una construcción muy fuerte que resistió a los diversos ataques; lo débil era el busto, pues era hueco y recubierto de cobre. Según Pedro Chaparro (entrevista, 2019), siempre hubo preocupación por parte de los organizadores en torno a la seguridad del monumento, pues eran conscientes de que podría provocar alguna reacción entre los sectores militares y políticos de derecha. Pero, a su juicio, se descuidaron una vez estuvo fundida y consolidada la base, más aun cuando comenzó a llegar gente de todo el país para los eventos programados el 15 y 16 de febrero de 1986.

De hecho, la efeméride se iniciaba en la tarde del viernes 14 con una ceremonia religiosa en la que se iba a bendecir el busto, según Vanguardia Liberal (16 de febrero, 1986, p. 13), ceremonia que fue abruptamente cancelada por el obispo de Barrancabermeja, monseñor Juan Francisco

14 Era la segunda escultura que hacía Güiza en la ciudad. La primera fue en homenaje a Alejandro Galvis Galvis en la avenida que lleva su nombre (Vanguardia Liberal, 17 de febrero de 1986, p. 11). El mismo informe del periódico dice que el busto le costó a Fedepetrol la suma de $\$ 300000$. A algunos no les gustó la obra de Güiza, pues decían que no empataba con el pedestal (entrevista a Pinzón, 2019).

15 La fuente de esta información es una de las fotos que Vicente Zamudio nos facilitó para esta investigación. Hay otra placa en la parte inferior de la $\mathrm{V}$, pero su texto es ilegible en la foto; sin embargo, Pedro Chaparro recuerda que la otra placa rezaba así: «Sobre las agrestes montañas de Colombia, la victoria para Camilo fue truncada en la mitad de su vida, es deber del pueblo con sus luchas completarla» (entrevista, 2019). 
Sarasti. Por su parte, la revista Solidaridad afirma que el obispo prohibió que el sacerdote jesuita Gonzalo Amaya hiciera una «liturgia de la palabra» con una homilía que previamente había sido aprobada por el prelado. La revista aduce que monseñor Sarasti se dejó amedrentar por los militares, quienes estaban molestos con el monumento y habían estado indagando por las instancias oficiales que lo habían aprobado (Solidaridad, 72, marzo de 1986, p. 33).

Para el día 15 de febrero se habían programado dos actos: uno público y masivo consistente en una marcha por la ciudad que culminaría en el monumento y otro más privado en el Club Infantas de la USo en las horas de la tarde; para el día siguiente estaba planeada la peregrinación a Patio Cemento (entrevista a Chaparro, 2019). Ahora veamos en efecto cómo ocurrieron los hechos que pusieron sobre el escenario público una álgida disputa en torno a la memoria del sacerdote revolucionario.

Una vez se supo del atentado en la madrugada del sábado 15, tanto los locales como los que acudieron de varias partes del país —estudiantes, sindicalistas, campesinos, mujeres, políticos y religiosos (entrevistas a Chaparro y Zamudio, 2019) - comenzaron a llegar al parque entre sorprendidos y atemorizados. Rápidamente se repusieron e iniciaron una marcha por la ciudad, como estaba programada, antes de que el sol de mediodía lo impidiera. Mientras tanto, se había cubierto la escultura maltratada con una sábana (ver foto en anexo 1) ${ }^{16}$.

16 En una noticia sobre el posterior atentado al resto del busto, Vanguardia Liberal trae a colación unas palabras pronunciadas por un supuesto sacerdote presente en los eventos. Según el prelado, «Le tienen tanto miedo al pensamiento de Camilo, que le cortaron la cabeza», a lo que agregó con sorna, «mientras la de tantos próceres permanecen llenas de telarañas en las calles (...)» (24 de noviembre de 1986, p. 21). Esto es un ejemplo más de lo que señalábamos en la primera sección: en el caso del monumento a Camilo Torres Restrepo, se trató de un proceso promovido desde abajo, claro que, con aceptación de la institucionalidad, al menos del municipio. En todo caso, como señala Achugar, este monumento también expresa una celebración de poder: «el poder tener el poder de monumentalizar» (2003, p. 206). 
Según Chaparro y Zamudio (entrevistas, 2019), el acto en el Club Infantas también se celebró en las horas de la tarde, según lo diseñado, solo que el lugar estaba atestado de gente, más de la que originalmente se esperaba. Para comenzar, hicieron uso de la palabra el sacerdote Bernardo López y el abogado Eduardo Umaña Mendoza ${ }^{17}$; luego, intervinieron líderes populares y políticos de la región y, según Solidaridad, «el acto se cerró con una sencilla pero bellísima "cantata”. Un grupo artístico declamó textos alusivos a la vida del pueblo y de Camilo, y simultáneamente acompañó con canciones e instrumentos» (n. ${ }^{\circ}$ 72, marzo de 1986, p. 33). Lo que no estaba en el libreto fue la irrupción de un comando del ELN compuesto por cuatro hombres y dos mujeres, mientras se desarrollaba el acto conmemorativo (entrevista a Chaparro, 2019). Así lo relata la prensa regional: «Los elementos del ELN estaban encapuchados, portaban armas y criticaron la destrucción del busto de Camilo Torres, considerándolo como un acto de la derecha, a la vez que repartieron el último de sus boletines entre los asistentes» (Vanguardia Liberal, 17 de febrero, 1986, p. 11).

Los eventos continuaron según estaban programados. La revista Solidaridad (n. ${ }^{\circ}$ 72, marzo de 1986, p. 33) dice que la peregrinación a Patio Cemento del domingo 16 consistió en una caravana de buses que salió a las 6 a. m. de Barranca y se topó en el camino con un par de retenes militares en los que hubo roces y resultaron algunos visitantes detenidos ${ }^{18}$. Finalmente, los participantes —en número entre 600 y 1000, según Vicente Zamudio, o 5000 según Pedro Chaparro (en las respectivas entrevistas, 2019) - , después de dejar los buses caminaron por un trecho corto para llegar al mediodía a un descampado donde había una piedra elevada con la placa conmemorativa y encima una cruz

17 Ambos asesinados años después, en situaciones distintas, pero supuestamente por paramilitares en los dos casos.

18 Según Pedro Chaparro (entrevista, 2019), los campesinos de la zona habían hablado con integrantes del ELN para que no entorpecieran los actos conmemorativos y más bien ayudaran a proteger a los peregrinos. 
(Vanguardia Liberal, 13 de marzo de 1986, p. 13) ${ }^{19}$. La misa fue presidida por el párroco del corregimiento El Carmen de San Vicente de Chucurí, padre Bernardo Marín, quien esta vez sí contó con la aprobación del obispo Sarasti (Solidaridad, 72, marzo de 1986, p. 33) (ver foto anexo 2). El sacerdote, según la prensa regional, declaró «tierra santa» el lugar (Vanguardia Liberal, 13 de marzo de 1986, p. 13). Luego de almorzar de una olla colectiva, y antes de que cayera la tarde y se hiciera noche, los peregrinos iniciaron el regreso al puerto petrolero al que llegaron sin novedades para luego dispersarse a sus lugares de origen ${ }^{20}$.

Sin embargo, no pasaron dos semanas cuando de nuevo se reportaron actos vandálicos contra la memoria de Camilo Torres Restrepo, esta vez en el monumento en Patio Cemento. Así lo narra Vanguardia Liberal: «diez días después, campesinos de la zona indicaron que tanto la placa como la cruz había (sic) sido tumbada y desaparecida. Igual suerte corrió (sic) las vallas ubicadas a 10, 5 y 2 km que servían de guía para llegar al lugar» (13 de marzo de 1986, p. 13) $)^{21}$.

19 La placa decía: «Sitio donde cayo (SIC) combatiendo el sacerdote revolucionario CAMILO TORRES RESTREPO, junto a el (sic) cayeron Aurelio Plata, Domingo Leal, Álvaro Millán, Bernardo Osorio y “Camilito”. CAMILO vive en el corazón de los colombianos. COMITE (SIC) CHUCUREÑo, 1966-15 de febrero-1986». De nuevo, la fuente para este texto son las fotos cedidas por Vicente Zamudio.

20 La revista Solidaridad termina la crónica titulada «Camilo Torres es “asesinado” por segunda vez» con una nota preocupante, según la cual Dagoberto Güiza, el escultor del busto, fue secuestrado en una calle de Bogotá el 17 de febrero del mismo año por unos individuos en un carro «quienes lo interrogaron sobre sus actividades», para luego aparecer drogado en un potrero de Soacha (n. ${ }^{\circ} 72$, marzo de 1986, p. 33). Ninguna otra fuente escrita ni oral menciona esta inquietante noticia, que, de haber sido cierta y aunada a lo ocurrido en Patio Cemento y, por segunda vez, en Barrancabermeja meses después, mostraría que la idea de silenciar la memoria de Camilo Torres Restrepo no fue algo estrictamente local y pasajero. Se cumple así la sentencia inicial de Achugar (2003) sobre la pugna entre quienes quieren recordar y quienes quieren borrar una memoria.

21 De acuerdo con el mismo periódico, los daños fueron del orden de $\$ 100000$. Nos llama la atención la insistencia de Vanguardia Liberal en cuantificar los costos de las obras en honor a Camilo Torres. Para Pedro Chaparro (entrevista, 2019), los autores de este nuevo vandalismo fueron «paramilitares». 
En cuanto al monumento en Barranca, según Vanguardia Liberal, el 24 de noviembre del mismo año, a las 2:41 con 22 segundos de la madrugada, explotó una carga de dinamita que voló lo que restaba del busto. La noticia señala que algunos locales comerciales y viviendas cercanas fueron afectados por la onda explosiva, y que los barranqueños no salían de su asombro por el nuevo atentado ${ }^{22}$. Incluso, avanza en la idea de que pareciera que el cura guerrillero «ha sido condenado a desaparecer» (Vanguardia Liberal, 25 de noviembre, 1986, p. 21). Recuerda el periódico lo ocurrido el 15 de febrero en el parque Camilo Torres y pocos días después en Patio Cemento. En esos meses la gente se preguntaba cuándo volvían a poner la cabeza al busto, hasta que pasó este nuevo atentado. La foto de Vanguardia muestra a la gente dispersa y sorprendida, lo que contrasta con la foto del anexo 3, tomada pocos días después, en la que se ve la gente dispuesta a marchar con pancartas. Fue una muestra de rechazo al nuevo ataque al monumento; pero el daño ya estaba hecho. Con el paso del tiempo, sin que la comunidad pudiera proteger lo que quedaba de la obra, los vándalos se robaron las placas que yacían en su base, con lo que se suprimieron los símbolos físicos del personaje que se quería conmemorar.

Sin embargo, la gente se buscó sus maneras de seguir recordando a Camilo Torres Restrepo, aunque sin llamarlo de esa forma; con cierta chispa caribeña que aún se respira en la ciudad, por un tiempo se le conoció como el parque del «Descabezado». Además, se volvió uno de los lugares emblemáticos de las movilizaciones sociales y políticas en Barrancabermeja (Chaparro, 1991 y García, 2006). Decenios más

22 Una versión similar nos contó Pedro Chaparro (entrevista, 2019). Para Fernando Acuña (video, 2010), los responsables del nuevo ataque fueron las «fuerzas oscuras del régimen», quienes ahora destruyeron todo el busto para que no se siguiera hablando del «Descabezado». En algunos recuerdos se fusionan los dos atentados o se dice imprecisamente que el 15 de febrero fue ametrallado o volado el monumento (ver, por ejemplo, la información del portal https://barrancabermejavirtual. net/wp/2015/05/05/camilo/). El testimonio de Luisa Delia Piña señala vagamente: "antes de la inauguración, como a las 5:30 de la mañana, sonó una bomba, le volaron la cabeza al busto (...)» (citada en Arenas, 1999, p. 78). 
tarde, durante la alcaldía de Carlos Contreras (2008-2011), el monumento fue restaurado ${ }^{23}$. Según cuenta Ramón Rangel (entrevista, 2019), en ese entonces miembro de la Junta de Acción Comunal del barrio Galán, hubo una partida presupuestal limitada que no dio para arreglar todo el parque, sino solo la plazoleta que rodeaba al monumento ${ }^{24}$. Como no se consiguió al escultor de la primera estatua, fue necesario poner un nuevo busto que ha tenido críticas por no parecerse a la imagen del sacerdote y por ser todavía más pequeño que el original. También se arregló la base del monumento, pero solo las montañas onduladas sin los animales diseñados originalmente (ver foto anexo 4). El mismo testigo dice que el parque fue reinaugurado un 3 de febrero - sin precisar el año, posiblemente a finales de la alcaldía de Contreras- para rescatar el natalicio de Camilo Torres Restrepo, evento que también contó con actos culturales y académicos (entrevista a Rangel, 2019).

Lo que sí se sabe con certeza es que el 15 febrero de 2016 se hicieron actos en torno a los 50 años de la muerte de Camilo Torres Restrepo. Fue una nueva disputa por la memoria, sobre todo por la peregrinación del «amor eficaz» a Patio Cemento, rechazada por las autoridades de San Vicente de Chucurí, mientras el ELN llamaba a un paro armado para conmemorar la fecha (Colectivo de abogados, 2016) ${ }^{25}$.

23 David Ravelo (entrevista, 2019) dice que hubo una reinauguración cuando él estaba al frente de la Oficina de Valorización de la ciudad, pero lo ubica vagamente en 1993, por lo que nadie más corrobora esa fecha.

24 De acuerdo con Fernando Acuña (video, 2010), los pobladores de la Comuna 2 apoyaron la financiación de la obra con «presupuesto participativo».

25 En ese mismo año hubo un debate promovido por estudiantes y profesores de la Universidad Nacional de Colombia sobre la pertinencia de mantener las imágenes del Che y Camilo Torres en la plaza central de la sede de Bogotá. Esto surgió a propósito de la borrada parcial de la imagen del Che y la posterior aparición a su lado del rostro de Jaime Garzón, humorista egresado de la Universidad y asesinado por paramilitares en 1999. Según escribió David Torres el 21 de octubre de 2016 en el portal Las Dos Orillas (2016), tales acciones reflejan un cambio generacional y social en las universidades públicas, o al menos en la Nacional. El autor recuerda que en agosto de 2005 hubo un par de demandas de un estudiante de Derecho para suprimir esas imágenes, dizque porque afectaban el patrimonio cultural de la 


\section{El círculo vicioso de la violencia}

Así como el parque del «Descabezado» o de Camilo Torres fue un lugar emblemático de la lucha social en Barrancabermeja, también la violencia simbólica ejercida contra la memoria del sacerdote revolucionario parecía ser una advertencia de lo que se vendría sobre el puerto petrolero, el Magdalena Medio y el país en general. Si volvemos a observar la figura 1, notamos que hay una relativa estabilidad en las luchas sociales posteriores a febrero de 1986, con la excepción de 1993, por la ya señalada ola de invasiones. Pero lo más notorio de esos años, como lo señala Martha Cecilia García (2006, p. 287), es que se cayó en un círculo vicioso entre protesta y violencia. No se trataba solo del incremento de las luchas urbanas y rurales, sino de la presencia cada vez más visible de los grupos guerrilleros en ellas, especialmente desde 1987, lo que a su vez estuvo acompañado de la aparición cada vez más ofensiva de los paramilitares en connivencia con sectores empresariales, estatales y de las fuerzas armadas.

Esto es lo que en la época se conoció como la «guerra sucia» que se generalizó por todo el país, pero con epicentros como el Magdalena Medio. Para ilustrarlo basta recordar con la misma investigadora que el 21 de abril de 1987 tres miembros de la UP y uno de la Coordinadora Campesina del Magdalena Medio sufrieron un atentado con granada, que dejó un muerto y tres heridos. Una semana después fue asesinada la niña Sandra Rondón Pinto, quien había sido testigo del atentado. El paro cívico que desató este asesinato duró tres días en los que se mostró ira y dolor, pero también la irrupción de comandos guerrilleros que al final hicieron descargas de fusil. El 12 de octubre del mismo año, al otro día del asesinato de Jaime Pardo Leal, también hubo una protesta en la que la guerrilla tuvo combates con el Ejército; en el cruce de balas

nación —al dañar los edificios de la plaza Che-; los tribunales de justicia fallaron a favor del demandante, por lo que temporalmente fueron borradas. Se trata de nuevas disputas en torno a la memoria, sobre las que volveremos al final de este artículo. 
murió un niño en el barrio Palmira. El 15 de enero de 1988 fue asesinado el dirigente sindical y artista Manuel Gustavo Chacón, lo que provocó un paro local de cuatro días. «El 18 (de enero) hubo nuevamente un enfrentamiento armado con un saldo de tres muertos y 17 heridos»; así concluye García el breve recuento de la violencia en Barrancabermeja en los años siguientes a los hechos narrados (p. 288).

Este círculo vicioso de violencia/resistencia/retaliaciones continuó en los años noventa, hasta producirse la llegada abierta del paramilitarismo, que fue desplazando de las comunas y veredas a las guerrillas, especialmente al ELN, algunas de cuyas estructuras urbanas sorpresivamente se cambiaron de bando. Como dice la misma Martha Cecilia García, apoyada en Adam Isacson, la masacre del 16 de mayo de 1998, perpetrada por el paramilitarismo, marcó el tránsito de asesinatos selectivos a acciones militares de gran escala (pp. 291 ss.). Aunque la población respondió en esa ocasión con un paro cívico de una semana, el terror había penetrado hondo en la ciudad; el orden paramilitar se impuso por un buen tiempo y, aun cuando formalmente se haya superado desde mediados del decenio anterior, el temor y el silencio siguen flotando en la ciudad y la región. Incluso la derrota de la huelga de la USO en 2004 (Vega et al., 2009) parece hacer parte de esta ofensiva de las fuerzas de derecha que vieron con preocupación el desborde de la insurgencia que cabalgaba sobre la amplia movilización social, de la que tradicionalmente hizo gala el puerto petrolero (entrevista a Rangel, 2019; ver también entrevistas a Chaparro y Ravelo, 2019) ${ }^{26}$.

A juicio de Ramón Rangel, en tiempos recientes hay una especie de pacto entre las autoridades barranqueñas - algunas de ellas tuvieron orígenes remotos en la izquierda, pero hoy se ubican al otro lado del

26 Según el mismo Ramón Rangel, en 1996, cuando se trajo la antorcha olímpica a Barranca y se colocó en el parque Camilo Torres, el ELN hizo una acción para que la sacaran de allá, lo que finalmente ocurrió. Parecía que esta guerrilla no quería que perturbaran la memoria de Camilo o que se transformara el simbolismo del parque como un espacio de movilización y lucha (entrevista, 2019). 
espectro político - con empresarios y aun con líderes sociales y sindicales por suprimir la memoria combativa de la ciudad. Esa misma impresión arroja el libro de la antropóloga norteamericana sobre Barrancabermeja, Lesley Gil (2016): parecería que la historia reciente de la ciudad fue la de un cambio extremo de una cultura radical obrera y ciudadana, que predominó entre los años veinte y los ochenta del siglo $\mathrm{xx}$, a una cultura individualista y fragmentada, implantada de los años noventa para acá, al abrigo del orden paramilitar aupado en el proyecto neoliberal imperante en el país desde esos años. Pero creemos que la historia no suele ser tan plana ni lineal; ni tal vez Barranca era tan revolucionaria en sus inicios como tampoco es absolutamente neoliberal en estos tiempos. Hay aún rasgos de una cultura política radical. De hecho en la ciudad triunfó el SÍ en el plebiscito sobre la paz de 2016 y el candidato de izquierda Gustavo Petro ganó por amplio margen en las dos rondas para la elección de presidente en $2018^{27}$. Pero, sin duda, el giro de los años ochenta y noventa la marcó, y en ese proceso la violencia simbólica -y física- contra la memoria de Camilo Torres Restrepo debió ser un campanazo de alerta que no siempre se percibió así.

\section{Conclusión}

Varios de los entrevistados señalaron que el monumento del que hablamos era transgresor de la cotidianidad no solo del país, lo cual era obvio, sino aun de la de Barrancabermeja; incluso, algunos reconocen que podía ser tomado como una afrenta por la derecha o por las fuerzas armadas estatales y paramilitares (entrevistas a Chaparro y Rangel, 2019). En efecto, los organizadores tuvieron ansiedad durante la construcción del monumento pues temían un ataque de esos sectores, y

27 En el plebiscito de 2016 en Barrancabermeja el Sí ganó por estrecho margen, $50,5 \%$, algo divergente del resto del departamento de Santander, en donde el NO triunfó con el 55,6\%. En cambio, los datos de la elección presidencial son más contundentes: si en la primera vuelta presidencial Petro sacó $42,4 \%$ de los votos seguido de Iván Duque con $25,5 \%$ y Sergio Fajardo $20,4 \%$, en la segunda ronda Petro obtuvo el 62,5 \% contra 34,2\% de Duque (Colombia.com). 
solo respiraron tranquilos cuando se terminó la base y el pedestal. Pero descuidaron la escultura, que era lo más débil de todo el homenaje.

En este punto no sobra hacer una reflexión breve sobre el hecho de que el parque en honor a Camilo Torres Restrepo en Barrancabermeja - según nuestro conocimiento- es un espacio público municipal único en Colombia. Aunque hay otros lugares públicos dedicados a él en el país, especialmente auditorios, edificios y plazoletas en varias universidades públicas, además de algunos colegios públicos y unos cuantos barrios bautizados con su nombre -incluso sabemos que hay una nueva estatua suya en Barranquilla, un tanto estrafalaria a nuestro juicio-, el parque de Barranca sigue siendo especial por ser el primero erigido explícitamente en su nombre - aparte de los señalados espacios universitarios-, por los múltiples ataques que ha recibido y, sobre todo, por el simbolismo que la población le ha otorgado en un persistente acto de memoria.

En ese sentido, se entiende el carácter transgresor del monumento ante la cultura política nacional de ese entonces, incluso en una ciudad de tradición radical como Barrancabermeja. Pero, inmediatamente, junto con algunos entrevistados, debemos señalar que al Camilo Torres Restrepo que se le ha rendido homenaje es al político y no al guerrillero como tal (entrevista Schmalbach, 2019). De hecho, los dos bustos que se han erigido sucesivamente en su nombre muestran a un hombre desarmado con la figura que tuvo en su corta carrera política como impulsor del Frente Unido del Pueblo y, en calidad de tal, pasó por el puerto petrolero en un 24 de julio de 1965. No obstante, para nadie es un secreto que hay un reconocimiento de su opción guerrillera en muchos componentes de los monumentos que se hicieron tanto en el puerto petrolero como en Patio Cemento. La $\mathbf{V}$ de la victoria truncada, la apelación a las montañas y los símbolos del campo, cuando no las cargadas palabras que se pusieron en las placas conmemorativas, hablan de esa dimensión constitutiva de su trayectoria revolucionaria. Y aunque el ELN siempre estuvo vigilante en el proceso de construcción 
del monumento y en su evolución posterior, a veces con excesivo celo, la gente de Barranca supo homenajear a Camilo a su modo, sin someterse a sus requerimientos.

Esto se plasmó en la disputa por el nombre del parque. Según Roberto Schmalbach (entrevista, 2019) el uso del «Descabezado» fue una forma cultural barranqueña de hablar de lo ocurrido sin mencionar al sacerdote revolucionario. Ramón Rangel (entrevista, 2019) añade que incluso un afiliado de la USo, quien tenía un negocio cercano al parque, lo registró oficialmente como «enfrente del Descabezado». Pero en general estos testigos suelen referirse críticamente a este nombre, pues ocultaría la verdadera intención de erigir un monumento a un hombre con clara trayectoria revolucionaria.

Por su parte, Fernando Acuña (2010) reivindica parcialmente el inicial carácter crítico del nombre del «Descabezado», para enrostrarles a los autores desconocidos el atentado que habían ejecutado. Según Pedro Chaparro parece que con la decapitación del busto los perpetradores del ataque inicial quedaron muy molestos, pues de ahí salió espontáneamente la consigna: «Camilo sin cabeza o con cabeza seguirá con la misma fortaleza» (entrevista, 2019). Por eso, unos meses después completaron la tarea al volar totalmente la escultura. Hoy en día, con la reinauguración, ha vuelto a llamarse parque Camilo Torres Restrepo, pero no deja de resurgir la memoria del «Descabezado»; despolitizadora para unos, pero significativa de la resistencia barranqueña para otros ${ }^{28}$.

28 Recientemente vuelven a aflorar estas disputas, ya no solo en Barrancabermeja, sino en el país, incluida la Universidad Nacional de Colombia. Por ejemplo, con la intención de cobrarle al ELN el brutal atentado a la Escuela de Cadetes de la Policía Nacional el 17 de enero de 2019 - hecho a todas luces condenable por cobrar la vida de 21 seres humanos y por la torpeza política de cerrar el difícil diálogo con el gobierno de Duque-, un profesor de la sede de Bogotá, a través de las redes de la institución, le solicitó a la rectora borrar las imágenes del Camilo guerrillero en la pared de la biblioteca central, dizque para que ese grupo no siguiera haciendo proselitismo armado en el campus. Esto provocó un álgido debate profesoral entre el 18 y el 20 de enero en el que, en forma tal vez exagerada, se le acusó de querer 
Estos son algunos de los avatares de una memoria colectivamente construida y espacialmente ubicada. Para recordar nuestras reflexiones iniciales, decimos que el monumento a Camilo Torres Restrepo en Barrancabermeja ha sido claramente un lugar de la memoria, en donde se libraron disputas culturales por su significado, entre ellas por el nombre. Lo que estaba en juego no era solo una pugna de poder por las distintas memorias en torno suyo, sino por su proyección futura, lo que tuvo tintes violentos de parte de los detractores del sacerdote revolucionario. Camilo fue guerrillero, eso no se puede negar, aunque fuera por corto tiempo, pero en su vida tuvo otras facetas: cristiano, sacerdote, profesor, sociólogo y político, por solo enumerar las más relevantes. Su memoria no es patrimonio de ningún grupo social, político o militar, como lo muestra el tesón del pueblo barranqueño para mantenerla viva a pesar de los ataques con mazo, dinamita, ametralladoras, vandalismo, terror y, sobre todo, silencios oficiales. Era un recuerdo local que, a fuerza de las circunstancias descritas, se generalizó.

Quedan varias preguntas sin contestar, por lo menos con el tipo de fuentes disponibles hasta el momento: ¿a qué responde el intento de acallar, silenciar o anular la memoria de Camilo Torres Restrepo?, ¿quiénes fueron realmente los autores - materiales e intelectuales - de los atentados descritos en estas páginas?, ¿eran grupos locales y regionales o contaron con alguna proyección nacional? Lo que sí es claro es que no consiguieron borrar esa memoria, pues el pueblo de Barrancabermeja volvió a erigir la estatua a nombre de Camilo Torres Restrepo

blanquear - literalmente- la memoria de la Universidad y negar que Camilo fue uno de sus profesores, además de capellán y fundador del departamento de Sociología. De nuevo estamos ante disputas por lugares de la memoria de Camilo Torres Restrepo, pero este caso muestra que no solo el ELN pretende apropiársela, sino que, del otro lado del espectro ideológico, también quieren endilgársela a ese grupo. Un evaluador anónimo de este artículo nos recordó que similares debates se dan en otras universidades públicas en las que se hace un explícito reconocimiento al rol guerrillero de Camilo como en la Universidad del Valle, donde hay un busto del sacerdote sociólogo empuñando un fusil, o en la Universidad de Antioquia cuyo auditorio central lleva el nombre «Comandante Camilo Torres Restrepo». 
y a recordar con él el pasado rebelde de la ciudad, pasado que la marca hasta nuestros días, aun cuando hoy esté más débil su tradición radical. Por eso, el Parque Camilo Torres sigue siendo un lugar emblemático para la lucha social y política en una ciudad que no olvida del todo al «Descabezado».

\section{Bibliografía}

\section{Fuentes primarias}

\section{Archivos}

Archivo documental ¡A Luchar!

Base de Datos de Luchas Sociales (BDLS) de Cinep

\section{Prensa}

Vanguardia Liberal (16 de febrero de 1986). «Desconocidos descabezan el busto de Camilo Torres».

Vanguardia Liberal (enero-marzo y noviembre de 1986)

Revista Colombia Hoy Informa, 1986.

Revista Solidaridad (marzo de 1986). «Camilo Torres es “asesinado” por segunda vez», n. ${ }^{\circ} 72$.

\section{Portales de internet consultados}

Barrancabermeja virtual (2015). ¿Por qué al Parque Camilo Torres lo llaman «El descabezado»? Recuperado de: https://barrancabermejavirtual.net/ wp/2015/05/05/camilo/

Colectivo de abogados (2016). Camilo 50 años: encuentros y desencuentros en Patio Cemento. Recuperado de: https://www.colectivodeabogados.org/?Camilo-50-anos-encuentros-y-desencuentros-en-Patio-Cemento

Las Dos Orillas (2016). Borrar al Che Guevara como protesta de las nuevas generaciones. Recuperado de: https://www.las2orillas.co/borrar-al-che-guevara-protesta-las-nuevas-generaciones/ 
Colombia.com (2016). Elecciones Plebiscito 2016. Recuperado de: https://www. colombia.com/elecciones/2016/plebiscito/resultados/?C $=\mathrm{PL} \& \mathrm{D}=27 \& \mathrm{M}=19$

Colombia.com (2018). Resultados elecciones presidenciales 2018. Recuperado de: https://www.colombia.com/elecciones/2018/resultados/presidente. aspx? $=\mathrm{P} 1 \& \mathrm{D}=27 \& \mathrm{M}=19$

\section{Entrevistas}

Chaparro, Pedro (2019). (Trabajador petrolero y dirigente de ¡A Luchar!). Barrancabermeja, 16 de enero.

Pinzón, Ciro (2019). (Trabajador petrolero). Barrancabermeja, 17 de enero.

Prieto, Jorge (2019). (Exdirectivo de la USO). Barrancabermeja, 17 de enero.

Rangel, Ramón (Moncho) (2019). (Líder político y activista social). Barrancabermeja, 17 de enero.

Ravelo, David (2019). (Activista y exjefe de valorización). Barrancabermeja, 17 de enero.

Schmalbach Cruz, Luis Roberto (2019). (Trabajador petrolero). Barrancabermeja, 17 de enero.

Zamudio, Vicente (2019). (Estudiante en ese momento de la Universidad Nacional y participante de los hechos descritos). Bogotá, 8 de febrero.

Videos

Acuña Rodríguez, Fernando (10 de agosto de 2010).

Aguirre, Marco Tulio (2016). Memoria Barranca 1. Recuperado de: https:// www.youtube.com/watch? $\mathrm{v}=\mathrm{Sftsn} 4 \mathrm{yP} 32 \mathrm{Y}$

\section{Bibliografía secundaria}

Achugar, Hugo (2003). El lugar de la memoria, a propósito de monumentos (Motivos y paréntesis). En Jelin, Elizabeth y Langland, Victoria (Eds.), Monumentos, memoriales y marcas territoriales. Madrid: Siglo XXI, 191-216.

Anderson, Perry (2008). El pensamiento tibio. Una mirada crítica sobre la cultura francesa. Crítica y Emancipación, 1, 177-234. 
Arenas Obregón, Martha (1999). Cerrando fronteras. Historias contadas del Magdalena Medio. Barrancabermeja: PDPMM.

Archila, Mauricio (1986). Aquí nadie es forastero. Revista Controversia, 133134.

Archila, Mauricio (1991). Cultura e identidad obrera. Bogotá: Cinep.

Archila, Mauricio (2017). Camilo y los movimientos sociales. En: Ramón Fayad, Juan Camilo Biermann y Mónica Chacón (Eds.), Camilo Torres Restrepo, sacerdote, profesor, activista, precursor, 29-47. Bogotá: Universidad Nacional de Colombia.

Archila, Mauricio (2018). Memoria, verdad e historia oral. Revista Controversia, 209.

Archila, Mauricio et al. (2006). Conflictos, poderes e identidades en el Magdalena Medio. Bogotá: Cinep.

Archila, Mauricio et al. (2019). Cuando la copa se rebosa: luchas sociales en Colombia, 1975-2015. Bogotá: Cinep.

Buenahora, Gonzalo (1971). La comuna de Barranca. Bogotá: Editorial Leipzig.

Chaparro, Jairo (1991). Recuerdos de un tropelero. Documento Ocasional, 63. Bogotá: Cinep.

Díaz, Apolinar (1988). Diez días de poder popular. Bogotá: Fescol/El Labrador.

García, Martha Cecilia (2006). Barrancabermeja: una ciudad en permanente disputa. En: Archila, Mauricio et al., Conflictos, poderes e identidades en el Magdalena Medio. Bogotá: Cinep, 243-311.

Gill, Lesley (2016). A century of violence in a red city: Popular struggle, counter insurgency, and Human Rights in Colombia. Durham: Duke University Press.

Gómez, Herinaldy (2000) De los lugares y sentidos de la memoria. En: Gnecco, Cristóbal y Zambrano, Marta (Comp.), Memorias hegemónicas, memorias disidentes; el pasado como política de la historia. Bogotá: Icanh/Colciencias/Universidad del Cauca. 
Halbwachs, Maurice (2004). La memoria colectiva. Zaragoza: Prensas Universitarias.

Hite, Katherine (2003). El monumento a Salvador Allende en el debate político chileno. En: Jelin, Elizabeth y Langland, Victoria (Eds.), Monumentos, memoriales y marcas territoriales. Madrid: Siglo XXI, 19-56.

Jelin, Elizabeth y Langland, Victoria (Eds.) (2003). Monumentos, memoriales y marcas territoriales. Madrid: Siglo XXI.

Koselleck, Reinhart (1993). Futuro pasado. Barcelona: Paidós.

Nora, Pierre (2008). Les liex de mémoire. Santiago de Chile: Editorial Lom.

Portelli, Alessandro (1997). The battle of Valle Giulia, oral history and the art of dialogue. Madison: The University of Wisconsin Press.

Prada, Esmeralda (2006). Las luchas campesinas en el Magdalena Medio, 1990-2001. En: Archila, Mauricio et al., Conflictos, poderes e identidades en el Magdalena Medio, 165-242. Bogotá: Cinep.

Rappaport, Joanne (1990). The politics of memory. Cambridge: Cambridge University Press.

Ravelo, David (2015). ¡Acúsenme! Bogotá: Oveja Negra.

Sandoval Ordoñez, Marbel (2018). En el brazo del río. Bogotá: Diente de León.

Vargas, Alejo (1992). Colonización y conflicto armado: Magdalena Medio santandereano. Bogotá: Cinep.

Vega, Renán, et al. (2009). Petróleo y protesta obrera, 2 vol. Bogotá: Corporación Aury Sará Marrugo/uso.

Velásquez Rodríguez, Rafael (2015). Luisa Delia Piña López: una luchadora popular. Revista CEPA, 20, 105-108. 


\section{Foto 1}

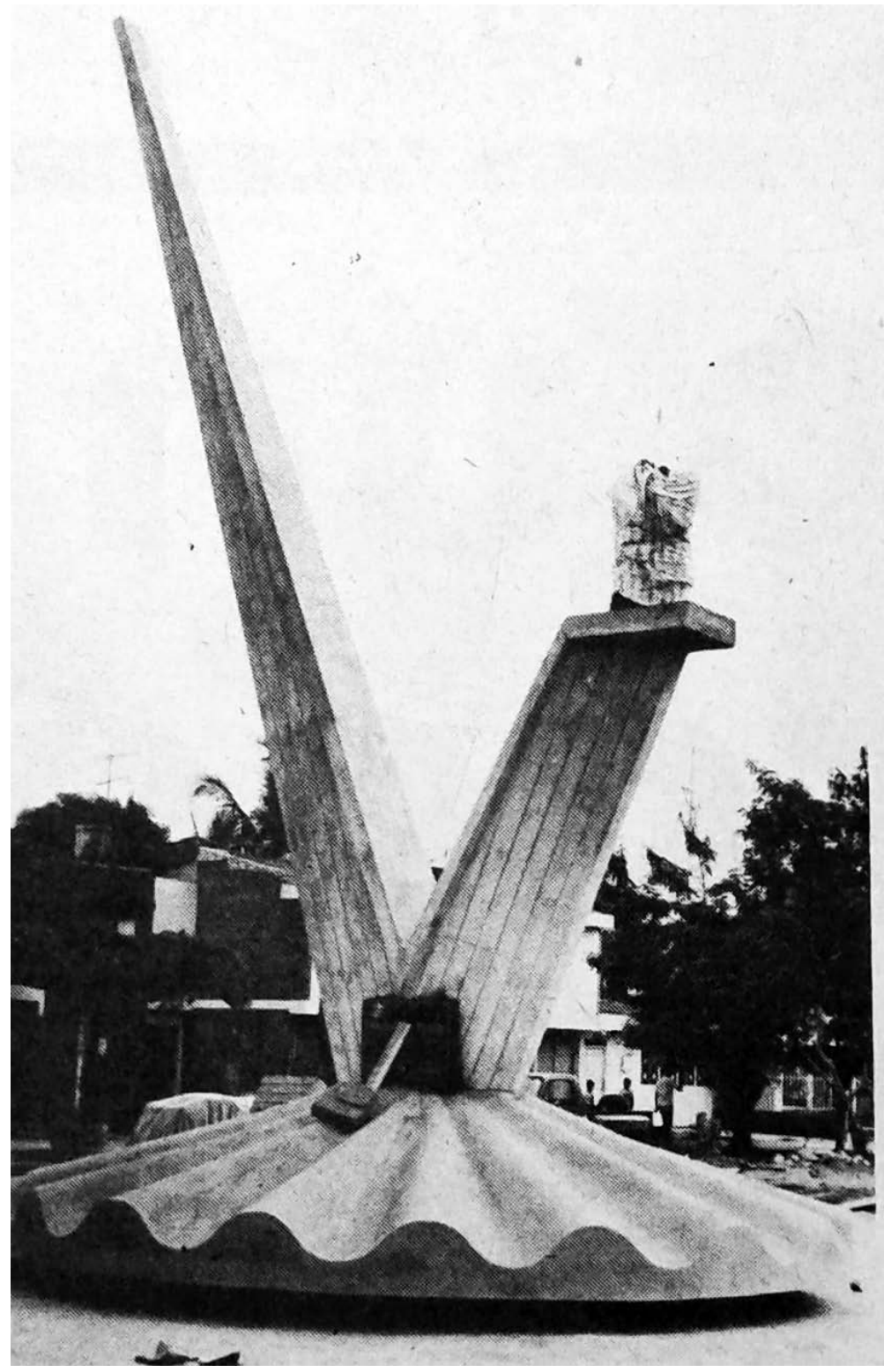

Fuente: Vanguardia Liberal, 16 de febrero de 1986, p. 13. 
Foto 2

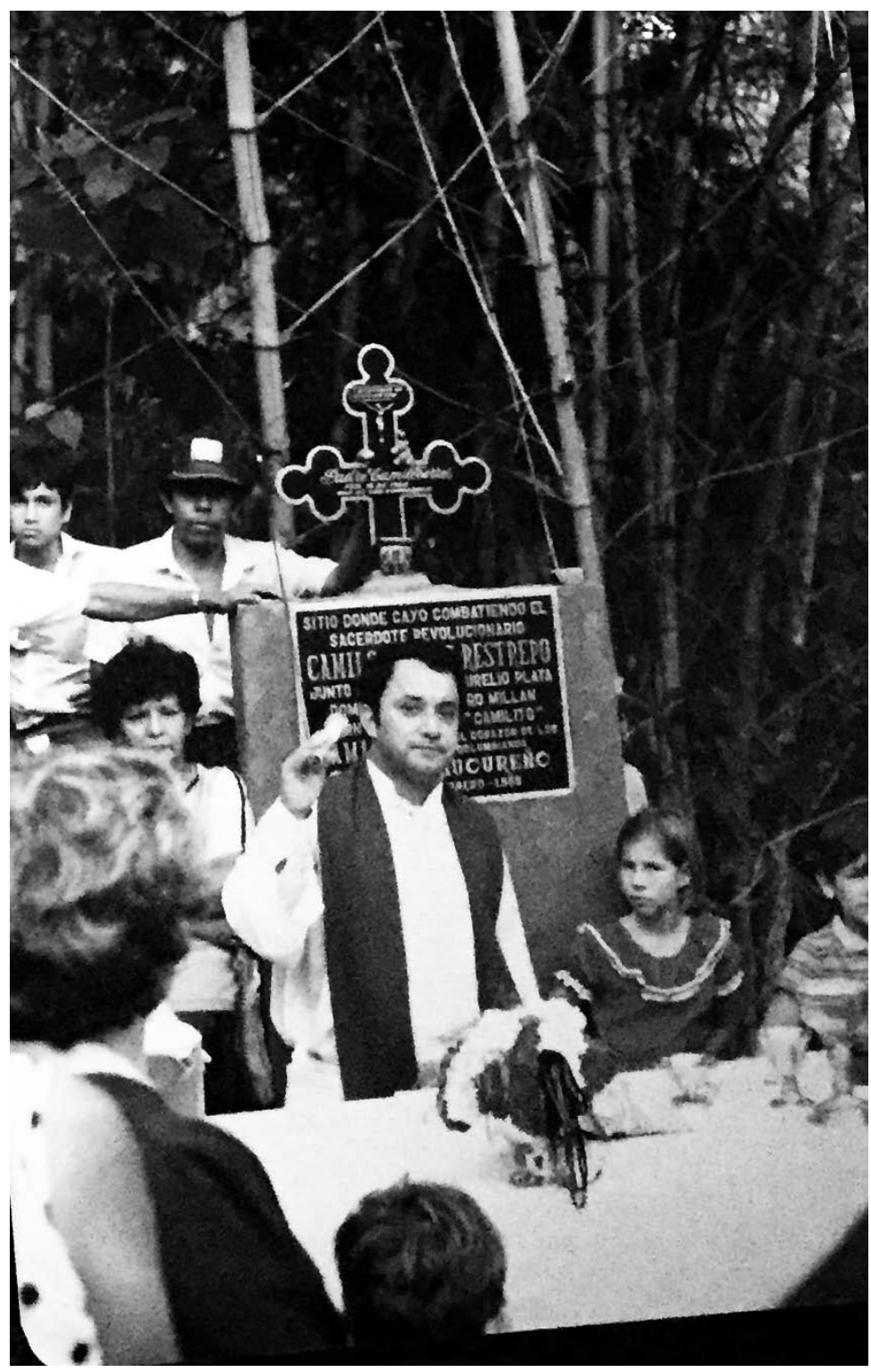

Fuente: Vicente Zamudio. Tomada el 16 de febrero de 1986. 


\section{Foto 3}

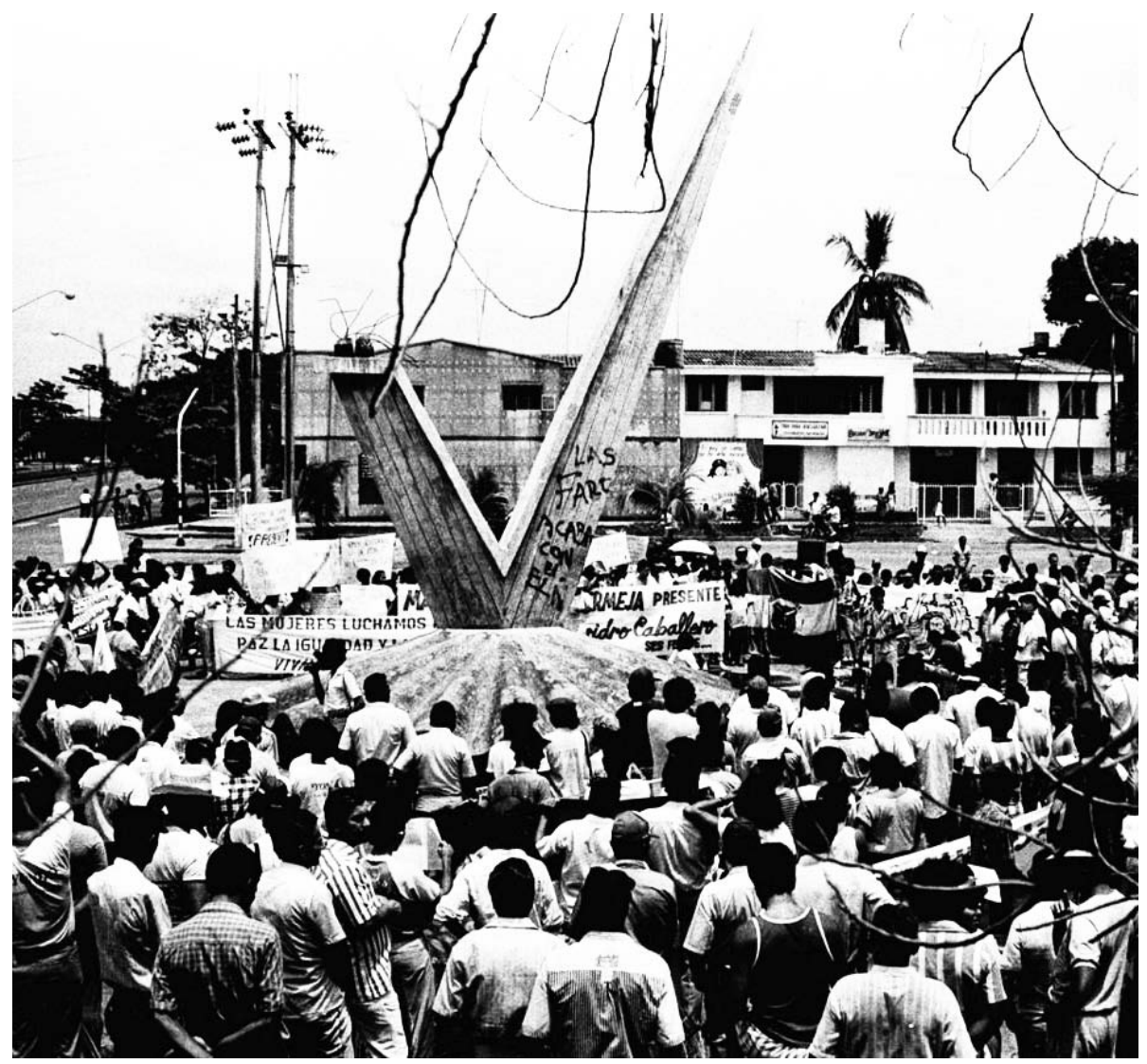

Fuente: Jesús Villamizar Rodríguez, 1986. Cedida por Rafael Velásquez Rodríguez. 


\section{Foto 4}

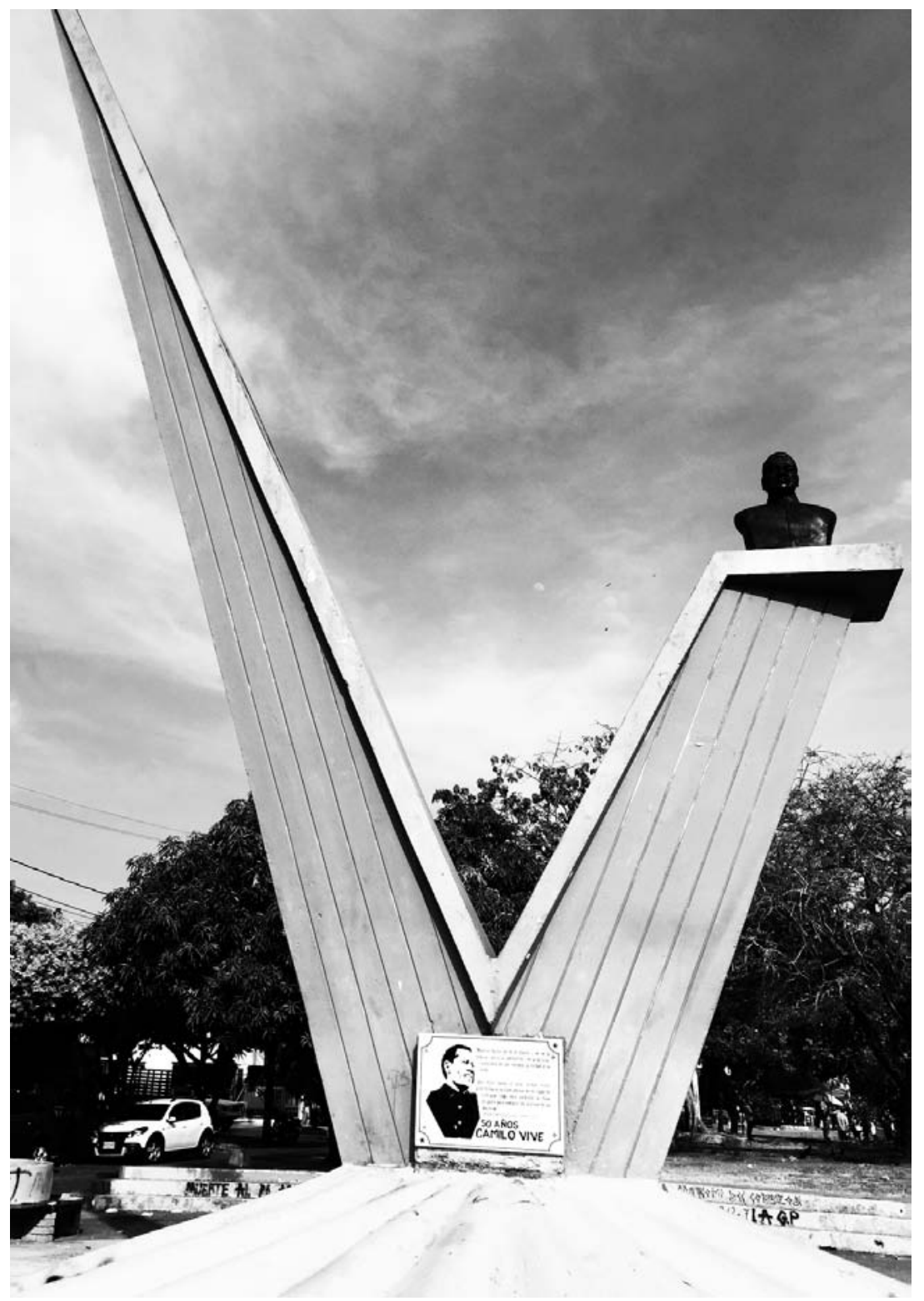

Fuente: Martha Cecilia García, 16 de enero 2019. 